\title{
PHYSICO-CHEMICAL PROPERTIES AND SENSORY QUALITIES OF JUICES EXTRACTED FROM FIVE SELECTED FRUITS AND THEIR PEELS
}

\author{
Agbaje, R.B., Ibrahim, T.A, Raimi, O.T. \\ Department of Food Science and Technology, Rufus Giwa Polytechnic, \\ PMB 1019, Owo, Ondo State, Nigeria
}

\begin{abstract}
The physico-chemical properties of juice, chemical composition of fruit peels and sensory qualities of some selected fruits (orange, apple, pawpaw, pineapple and mango) in the Nigerian market were evaluated to determine their overall quality. Results of the physico-chemical properties obtained show the following range of values for acidity $(0.40-1.06 \%)$, total solids (4.20 $8.20 \%)$, total sugar $(8.55$ - $13.39 \%)$, moisture content $(84.50-91.83 \%)$ and fruit juice content $(13.20-44.03 \%)$. The vitamin $\mathrm{C}$ for the juice samples orange, apple, pawpaw, pineapple and mango were 27.18, 22.10, 35.19, 37.14 and 41.07, respectively. The results showed that crude fat, protein, ash, crude fiber and carbohydrates contents in fruit peels were 4.52 to $9.65 \%, 2.60$ to $17.19 \%, 1.68$ to $10.70 \%, 5.10$ to $16.41 \%$ and 53.43 to $72.02 \%$ respectively. Pineapple juice was adjudged the best in overall acceptance (8.45). Generally, the juice samples were within the regulatory specifications, and are fit for consumption. Due to the proven health benefits of phenolic compounds, peels of these fruits can be used as good ingredients in formulation of health benefits food products.
\end{abstract}

KEYWORDS: Fruits, Physicochemical Qualities, Sensory, Peels, Juice

\section{INTRODUCTION}

Fruits are nature's wonderful gift to humankind and packed with vitamins, minerals, anti-oxidants and many phytonutrients (Umesh, 2009). Fruit are an absolute feast to our sight, not just because of their colour or flavour but also for their unique nutrients profile that help the human body free of diseases and stay healthy (Rudrappa, 2009). They are low in calories and fat and are a source of simple sugars, fibre and vitamins (Umesh, 2009). In addition, they are rich sources of vitamin $\mathrm{C}$, vitamin $\mathrm{A}$, sodium, potassium, magnesium and cellulose (Raheena, 2009) which are essential for optimizing our health. Fruits contain some antioxidants like polyphenolic, flavonoids and anthocyanin, which help human body to be protected from oxidative stress, diseases, and cancers and it help the body to develop capacity to fight against ailments by boosting the immunity level (Rudrappa, 2009). Pineapple (Ananas comosus) is an economically important plant in the Bromelanceae family that encompasses about 50 genera and 2000 species mostly epiphytic (Bartholomew and Maleieux, 2004). The worldwide total pineapple production is between $16-$ 19 million tons (Fernandes et al., 2008). Pineapple and its juice is non-alcoholic drink and the demand continues to rise mainly due to increasing awareness of its health benefits (Nwachukwu and Ezejiaku, 2014). Its juice have an proximate composition of 81.2 - $86.2 \%$ moisture, $13-19 \%$ total solid of which sucrose, glucose and fructose are the main compositions, $0.4 \%$ fibre and a rich source of vitamin C (Dull, 2000). Pineapple also contains polyphenolic compounds and possesses antioxidant activity (Hossain and Rahman, 2011). Its pulp is juicy and fleshy with the stem serving as a supporting fibrous core. It is an excellent source of antioxidant, vitamin $\mathrm{C}$ that is required for the collagen synthesis in the body. Pineapple juice is largely consumed around the world, mostly as canning industry by-products and in the blend composition to obtain new flavours in beverage and other products (De-Garvalho et al., 2007).

Mango (Mangifera indica L.) is one of the most important fruit trees in the tropics and subtropics. It originated from the Indian subcontinent and reached East Africa by 10th Century (Ensminger, 1994). It is commercially grown in more than 90 countries worldwide and is consumed both in fresh and processed form. Over one hundred varieties are produced worldwide, which have similar properties but specific differences peculiar to each variety (Bally et al., 2009). Orange (Citrus cinensis) belongs to the 


\section{International Journal of Engineering Applied Sciences and Technology, 2020 \\ Vol. 4, Issue 11, ISSN No. 2455-2143, Pages 239-244 \\ Published Online March 2020 in IJEAST (http://www.ijeast.com)}

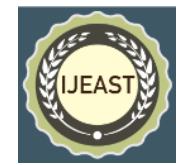

genus citrus of the family Rutaceae. It is a distinguished, widely consumed fresh fruits and particularly appreciated for its tangy taste. Its pulp is an excellent source of vitamin $\mathrm{C}$ providing $64 \%$ of the daily requirement of an individual. Apart from vitamin $\mathrm{C}$ content of orange juice, it's also rich in folic acid, potassium and excellent source of bioactive antioxidant phytochemical and they are important trade commodities in most countries (Nwachukwu and Ezejiaku, 2014).

Pawpaw (Carica papaya) is grown mostly for fresh consumption or for production of latex. C.papaya plants produce natural compounds (annonaceous, acetogenins) in leaf bark and twig tissues that possess both highly anti-tumour and pesticidal properties (Nwachukwu and Ezejiaku, 2014). The papaya fruit, as well as all other parts of the plant, contain a milky juice in which an active principle known as papain is present that has value as a remedy in dyspepsia and has been utilized for the clarification of beer. The juice has been in use on meat to make it tender, (De-Garvalho et al., 2007). The unripe fruit is used as a remedy for ulcer and impotence. It cleans bacteria from the intestines and hence encourages the absorption of vitamins and minerals, especially vitamin $B_{12}$.

Fruits peels are normally throw away as waste into environment but different phytochemicals present in them like in any other plant makes them important alternative source of natural of antioxidant/antinutrient (De-Garvalho et al., 2007). Hence, attention should be paid for proper extraction of these compounds and check their suitability as the rapentitice. This will increase the aggregate value of the agro industrial waste. The waste product from food forest or agricultural industries wastes (Kaneria et al., 2012a). The aim of this study is to determine the physico-chemical and sensory qualities of juice extracted from five selected fruit (pineapple, apple, mango, orange and pawpaw) and chemical composition of their peels.

\section{MATERIALS AND METHOD}

Collection of Fruits : The selected fruits used for this work (pineapple, apple, mango, orange and pawpaw) were obtained from Oba's market in Owo, Ondo state.

Processing of Raw Materials: The fruits (pineapple, apple, mango, orange and pawpaw) were washed thoroughly under tap water, followed by distilled water to remove foreign extraneous materials. The fruits that had been properly washed were hand peeled using kitchen knives. The pulp was separated from the seeds and peels. The pulp was reduced in size to increase the rate of extraction of liquid components and also for ease of blending. The blended pulp was extracted using sterilized white muslin cloth. Juice obtained was cloudy as some suspended particles were present. The peels were oven-dried at $37^{\circ} \mathrm{C}$ for 72 hours and then ground to fine powder.

Physicochemical Quality of the Fruit Juice: The $\mathrm{pH}$ and the total dissolved solids (TSS) were done using the method of Dauda et al.,(2017).The total titratable acidity (TTA) was done using the method of Lacey $e t$ al. (2009).The ascorbic acid (vitamin- C) content was determined by the method described by Dauda et al.,( 2017) with some modifications.

Chemical Qualities of the fruit peels: The chemical qualities of the fruit peels were done using the methods describe by AOAC (2005).

Sensory Evaluation: This was judged for colour, taste, flavour and general acceptability on a nine point hedonic scale, varying from "dislike extremely" (score 1) to "like extremely" (score 9). This was used according to the method of AOAC (2005).

\section{RESULTS AND DISCUSSION}

Table 1: Physico-chemical analysis of different brands of juice samples

\begin{tabular}{llllllll}
\hline Fruits & $\begin{array}{l}\text { Moisture } \\
\text { Content } \\
(\boldsymbol{\%})\end{array}$ & $\mathbf{p H}$ & TSS & TTA & $\begin{array}{l}\text { Total } \\
\text { Sugars }\end{array}$ & $\begin{array}{l}\text { Juice } \\
\text { content }\end{array}$ & Vitamins C \\
\hline Pineapple & $84.50 \pm 2.01$ & $4.00 \pm 0.10$ & $4.20 \pm 0.71$ & $0.40 \pm 1.10$ & $12.29 \pm 1.04$ & $13.20 \pm 1.29$ & $37.14 \pm 1.10$ \\
Mango & $91.83 \pm 3.11$ & $4.50 \pm 0.18$ & $6.37 \pm 1.05$ & $0.68 \pm 1.00$ & $13.20 \pm 0.95$ & $20.50 \pm 2.10$ & $41.07 \pm 0.15$ \\
Apple & $90.02 \pm 2.05$ & $3.60 \pm 0.70$ & $7.25 \pm 0.70$ & $0.85 \pm 1.04$ & $8.35 \pm 1.50$ & $29.03 \pm 1.80$ & $22.10 \pm 1.08$ \\
\hline
\end{tabular}


International Journal of Engineering Applied Sciences and Technology, 2020

Vol. 4, Issue 11, ISSN No. 2455-2143, Pages 239-244

Published Online March 2020 in IJEAST (http://www.ijeast.com)

$\begin{array}{llllllll}\text { Orange } & 88.20 \pm 2.01 & 3.23 \pm 0.10 & 8.20 \pm 0.95 & 1.06 \pm 1.07 & 9.56 \pm 0.08 & 44.03 \pm 1.30 & 27.18 \pm 0.05 \\ \text { Pawpaw } & 89.01 \pm 1.50 & 4.07 \pm 0.07 & 7.95 \pm 0.11 & 0.90 \pm 0.25 & 9.20 \pm 0.16 & 36.50 \pm 1.30 & 35.19 \pm 0.05\end{array}$

Data are mean values of duplicate determinations \pm standard deviation.

Table 2: Proximate Composition of Fruit Peels

\begin{tabular}{llllll}
\hline Fruits Peel & Crude Protein & Crude Fat & Ash & Crude Fibers & Carbohydrate \\
\hline Pineapple & $5.18 \pm 0.08$ & $5.73 \pm 0.70$ & $4.40 \pm 0.10$ & $14.85 \pm 0.05$ & $69.84 \pm 0.74$ \\
Mango & $5.09 \pm 0.09$ & $4.52 \pm 0.40$ & $3.28 \pm 0.15$ & $16.41 \pm 0.10$ & $70.70 \pm 0.92$ \\
Apple & $2.60 \pm 0.15$ & $9.65 \pm 1.80$ & $1.68 \pm 0.10$ & $14.05 \pm 0.05$ & $72.02 \pm 0.16$ \\
Orange & $14.77 \pm 0.02$ & $9.25 \pm 0.60$ & $10.70 \pm 0.55$ & $5.10 \pm 0.88$ & $60.18 \pm 0.44$ \\
Pawpaw & $17.19 \pm 0.77$ & $5.77 \pm 0.37$ & $10.22 \pm 0.05$ & $13.39 \pm 0.12$ & $53.43 \pm 0.55$ \\
\hline
\end{tabular}

Values are means \pm standard deviations of three replicate measurements

Table 3: Sensory Evaluation of Juice Samples

\begin{tabular}{lllll}
\hline Fruits Peel & Colour & Taste & Flavour & General Acceptability \\
\hline Pineapple & $4.16 \pm 0.87^{\mathrm{a}}$ & $3.82 \pm 0.96^{\mathrm{a}}$ & $5.16 \pm 0.71^{\mathrm{a}}$ & $7.32 \pm 0.66^{\mathrm{a}}$ \\
Mango & $4.10 \pm 0.07^{\mathrm{b}}$ & $3.02 \pm 0.16^{\mathrm{b}}$ & $4.17 \pm 0.75^{\mathrm{b}}$ & $7.02 \pm 0.06^{\mathrm{a}}$ \\
Apple & $3.84 \pm 0.90^{\mathrm{c}}$ & $2.83 \pm 0.73^{\mathrm{c}}$ & $3.74 \pm 0.83^{\mathrm{c}}$ & $5.16 \pm 0.68^{\mathrm{c}}$ \\
Orange & $4.03 \pm 0.90^{\mathrm{c}}$ & $2.83 \pm 0.73^{\mathrm{c}}$ & $3.74 \pm 0.83^{\mathrm{c}}$ & $5.14 \pm 0.88^{\mathrm{c}}$ \\
Pawpaw & $3.64 \pm 0.80^{\mathrm{a}}$ & $2.63 \pm 0.53^{\mathrm{c}}$ & $3.54 \pm 0.03^{\mathrm{c}}$ & $5.01 \pm 0.008^{\mathrm{c}}$
\end{tabular}

*Means within a row with different letters are significantly different at $\mathrm{P}<0.05$.

Juice is a liquid that is naturally contained in fruit. It is commonly consumed as a beverage or used as an ingredient or flavouring in foods. It is also consumed for their perceived health benefits. The results obtained from the physico-chemical analysis of the fruits juice samples are presented in Table 1. The moisture content in the fruit juice analyzed ranged from 84.50 to $91.83 \%$. Pawpaw had the lowest value of $84.50 \%$. The moisture content has an inverse relationship with the total fruit juice content. The $\mathrm{pH}$ of the juice samples range from 3.23 to 4.50. Mango had the highest $\mathrm{pH}$ value of 4.50. The reverse was observed in the results for acidity, in which orange had the highest value of $1.06 \%$, while pineapple, mango, apple and pawpaw had 0.40, 0.68, 0.85 and 0.90\%, respectively.

Kareem and Adebowale (2007) reported that the dominant acid in orange juice is citric acid. Food acids dictate the dominant microflora in foods and to a large extent will determine the shelf stability of the juice (Ezeama, 2007). The more acidic the juice, the less susceptible to bacterial action but the more susceptible to the action of yeasts and moulds (Jay, 2000). Moreover Anvoh et al. (2009) reported that fruit acids influence colour, flavour and gustative characteristics of the juice products. These results were similar to that reported by Braddock (1999) which had earlier reported on orange (0.7-0.8\%) and grape fruits (1.1-1.3\%) respectively. Its stability might be due to the stable concentration of the organic acid in the juice judging by the report of Fasoyiro et al., (2005) that says that increase in titratable acidity could be due to presence of preservatives, and in this work, no preservative was added to the juice produced.

The total solids content of the fruit juices were: $4.20,6.37,7.25,8.20$ and $7.95 \%$ for pineapple, mango, apple, orange and pawpaw respectively. The total (soluble and non-soluble) solids are used as 


\section{International Journal of Engineering Applied Sciences and Technology, 2020 \\ Vol. 4, Issue 11, ISSN No. 2455-2143, Pages 239-244 \\ Published Online March 2020 in IJEAST (http://www.ijeast.com)}

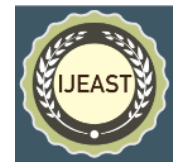

indicators of the fruit juice content that ranged from 13.2 to $44.03 \%$ in the orange juice samples. The total solids and juice content are used in characterizing the quality of juice and other beverage products (Egbekun and Akubor, 2007; Adubofuor et al., 2010) The stability which is an indication of the maturity of the fruits used might be part of the reason the juice was palatable and acceptable, as it can be deduced that reducing sugars are the main constituents of soluble solids.

The slight reduction noticed in the values of TSS might be due to the utilization of sugars by fermenting organisms, which could have led to the slight degradation noticed. This corroborated the report of Costa et al., (2003) for juice stored after hot fill and aseptic processing. The total sugar was highest in mango (13.20\%) and lowest in apple (8.35\%). The total (reducing and non-reducing) sugars to a large extent determine the sweetness of juices and beverages. It could be used for masking the astringency derived from organic acids (Anvoh et al., 2009; Adeola and Aworh, 2010). When compared with the recommended dietary allowances (RDA) of $130 \mathrm{~g} /$ day (El-Sheikha et al., 2010), for total sugars, the orange juice samples will contribute to the average $15.40 \%$. Wardlaw (2004) reported that frequent consumption of sugar sweetened beverages may be associated with larger weight gain and increased risk of type 2 diabetes.

It was observed that the vitamin $\mathrm{C}$ contents vary among the different brands of juices sample. Mango had the highest content of vitamin C (41.07 $\mathrm{mg}$ ) while apple had the lowest values of 22.10. Fruit juices are important in the delivery of body fluid and essential micro-nutrients such as vitamins (Landon, 2007) and the nutritional significance of food nutrients is related to their contribution to the recommended dietary allowance (RDA) (Wardlaw, 2004). Ascorbic acid content of fruit juices is the most prominent quality index of fruit juices due to its health significance as a vitamin and cellular antioxidant (Landon, 2007).

In the five analysed fruit peels, the protein content ranged from $2.60 \pm 0.15$ to $17.19 \pm 0.77 \%$; the minimum level was found in apple peel and the maximum in pawpaw peels. This protein content found in pawpaw peels $(17.19 \pm 0.77 \%)$ was comparable to $17.9 \%$ obtained by Munguti et al. (2006) but higher compared to the protein content $(14.1 \%)$ found in Solo pawpaw peel by Okai et al. (2010). The protein content in mango peel (5.09 \pm $0.09 \%$ ) was comparable to the crude proteins levels (4.68\% and $4.32 \%$ ) found in mango peels respectively by Omutubga et al. (2012). The crude fat of fruit peels ranged from $4.52 \pm 0.40$ to $9.65 \pm 1.80 \%$ with mango peels having the lowest content and apple peels the highest level. The crude fibre in apple peels, pawpaw peels, orange peels and in mango peels was comparable to the content obtained respectively in apple star peel (8.94\%) by Ukana et al. (2012), in pawpaw peel (5.78\%) by Okai et al. (2010), in orange peel $(9.52 \%)$ by Magda et al. (2008) and in mango peels $(4.80 \%)$ by Omutubga et al. (2012).

The ash content of fruit peels under study varied from $1.68 \pm 0.10 \%$ in apple peels to $10.70 \pm$ $0.55 \%$ in orange peels. Similar observations was made by Naseem et al. (2012) who reported that the ash content in different orange peels varied from 6.4 to $12.8 \%$. The concentrations of ash found in mango peels $(3.24 \pm 0.18 \%)$ were comparable to the level found by Naseem et al. (2012) in pawpaw peels (5.01 $\pm 0.14 \%)$ and in mango peels (3.88\%) by Omutubga $e t$ al. (2012).

The crude fibers and carbohydrates content of fruit peels respectively ranged from $13.39 \pm 0.12$ to $16.41 \pm 0.10 \%$ and from $53.43 \pm 0.55$ to $72.02 \pm$ $0.16 \%$. The crude fibres level observed in mango peels $(14.41 \pm 0.10 \%)$ was comparable to the content obtained with watermelon peels $(16.50 \pm 0.74 \%)$ by Ismail et al. (2014). However, the carbohydrates level observed in apple peels $(72.02 \pm 0.16 \%)$ was lower than $78.67 \%$ in apple peel by the same author. This might be due either to the differences in varieties of cultivars.

Table 3 summarizes the results for the sensory evaluation and overall acceptability of the juice samples. The statistical analysis revealed that there were significant difference $(\mathrm{p}<0.05)$ among the juice samples in the sensory attributes observed. Pineapple had the highest score (4.16), while pawpaw had the lowest score (3.64) for colour. The appearance was based on how the colours appeal to the panelists. Browning in the beverages could have been due to Maillard-type reactions (Potter and Hotchkiss, 2006) resulting from the presence of reducing sugars, proteins and amino acids, also, due to the effect of severe heating during processing on the quality attributes (Mannay and Shadaksharaswany,2005).

Similar trends were observed for the sensory ratings of flavour in the juice samples, pawpaw had the lowest scores (3.54) followed by orange and pineapple (3.74). Acidity contributes to the development of flavour through a proper sugar-acid ratio thereby modifying the sweetness of sugar (Adeola and Aworh, 2010). The residual after taste was characterized by perceived bitterness after swallowing the juice samples by the panelists. This bitter perception was prominent in pawpaw (2.63), apple, and orange (2.83). The panelists affirmed that this was responsible for their low scores on flavour and aroma. Mannay and Shadaksharaswany (2005), reported that the inclusion of additives could affect the organoleptic qualities of 


\section{International Journal of Engineering Applied Sciences and Technology, 2020 \\ Vol. 4, Issue 11, ISSN No. 2455-2143, Pages 239-244 \\ Published Online March 2020 in IJEAST (http://www.ijeast.com)}

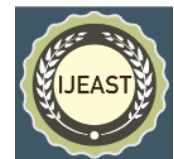

food products. Pineapple and mango had the best overall acceptability ratings of 7.32 and 7.02, respectively.

\section{CONCLUSION}

Consumption of these beverages is desirable as they would serve as good sources of vitamins and body electrolytes. The results from this study show that the orange juice samples would need to be supplemented with other nutrient sources in the diet to meet up with the RDA requirements for a healthy nutrition. The results also show that the juices samples were good for human consumption most especially pineapple and mango which had the best overall acceptability. It can be concluded from the research work that juice can be produced from varieties of fruits like pineapple, mango, apple, orange and pawpaw and could give a satisfactory and acceptable product, which can compare favourably with any commercial juice products. Citrus peels are good source of important nutrients and phytochemicals incorporation of citrus peels in food product may boost the flavor and acceptability of the product but also to have bioactive compound known for their health benefits.

\section{REFERENCES}

1. Adeola, A.A., Aworh, O.C. (2010). Development and sensory evaluation of an improved beverage from Nigeria's tamarind (Tamarindus indica 1.) fruit. Journal of Food Agric. Nutr. Dev. 10 (9):4079-4093.

2. Adubofuor, J., Amankwah, E, Arthur, B., Appiah, F. (2010). Comparative study related to physico-chemical properties and sensory qualities of tomato juice and cocktail juice produced from oranges, tomatoes and carrots. Afr. J. Food Sci. 4(7):427-433.

3. Anvoh, K., Zoro-Bi, A., Gnakin, D. (2009).Production and characterization of juice from mucilage of cocoa beans and its transformation to marmalade. Pak. J. Nutr., $8(2): 129-133$.

4. A.O.A.C. (2005). Official Methods of Analysis (22nd Edition). Association of Official analytical Chemists. Washington USA.

5. Bally, L.O. Okunrobo, E.G., UwumarongieIlori, E.O.(2009). Phytochemical screening, proximate and elemental analysis of Citrus sinensis peels (1.) Osbeck, J. Appl. Sci. Environ. Management, 17: 47-50.

6. Bartholomew, G. C. and Maleiux, D.H. (2004). Scavenging effect of methanolic extracts of peanut hulls on free-radical and active-oxygen species. J. Agric. Food Chem., 42: 629-632.

7. Braddock, R..J. (1999). Handbook of citrus by-products and processing technology. 2nd edt. Van Nostrand: New York.

8. Costa, M.C.O., Maia, G.A., Figueieredo, R.W., Souza, Filha MM and Brasil IM. (2003). Storage stability of cashew apple juice preserved by hot fill and aseptic process. Cienc. Tecnol. Aliment. Campinas. 23 (spl): 106-109.

9. Dauda, S., Hacisegerogullari, H., Ozcan, M., Arslan, D., (2017). Some Nutritional and Technological Properties of Wild Plum (Prunus spp) fruits in turkey, J. Food Eng. 66:233-237.

10. De-Galvalho, D., Ertekin C, Menges H.O., Guzel, E, Ekinci, K. (2007). Physical and Nutritional Properties of Oleaster (Elaeagnus angustifolia L.) growing in Turkey, Asian J. Chem. 20(3): 2358-2366.

11. Dull, J.H. (2000). The determination of sugar in blood and in spinal fluid with anthrone reagent. J. Biol. Chem., 212: 335- 343.

12. Egbekun, M.K. and Akubor, P.I. (2007). Chemical composition and sensory properties of melon seed- orange juice beverage. Nig. Food J., 24(1):42-45.

13. El-Sheikha A., Zaki M., Bakr A., El-Habashy M., Montet D (2010). Biochemical and sensory quality of physalis (Physalis pubescens 1.) juice. J. Food Process. Preserv. 34:541-555.

14. Ensminger A.H., Ensminger M.E, Kondale J.E, Robson J.R.K (1994). Foods and Nutrition Encyclopedia. Pegus Press, Cloris, California.

15. Ezeama, C.F. (2007). Food Microbiology: Fundamentals and Applications. Natural Prints Ltd. Lagos.

16. Fasoriyo S.B, Ashaye, O.A, Adeola, A. and Samuel, F.O. (2005). Chemical and Storability of fruit-flavoured (Hibiscus sabdariffa) drinks. World Journal of Agricultural Science. 2: 165-168.

17. Fernandes, Lilia Calderón-Jaimes, Eduardo Guerra-Hernández, Belén García-Villanov (2008). Antioxidant capacity, phenolic content and vitamin $\mathrm{C}$ in pulp, peel and seed from 24 exotic fruits from Colombia. Food Res. Int., 44: 2047-2053.

18. Hossain, J.S. and Rahman, L.O. (2011). Preliminary Evaluation for Comparative Antioxidant Activity in the Water and Ethanol Extracts of Dried Citrus Fruit (Citrus unshiu) Peel Using Chemical and 


\section{International Journal of Engineering Applied Sciences and Technology, 2020 \\ Vol. 4, Issue 11, ISSN No. 2455-2143, Pages 239-244 \\ Published Online March 2020 in IJEAST (http://www.ijeast.com)}

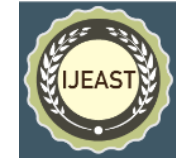

Biochemical in Vitro Assays, Food Nutri. Sci., 4: 177-188.

19. Ismail, T., Akhtar, S., Riaz, M. and Ismail, A. (2014) Effect of pomegranate peel supplementation on nutritional, organoleptic and stability properties of cookies, International Journal of Food Science and Nutrition, 1 (6): 36-43.

20. Jay MJ (2000). Modern Food Microbiology. (6th ed.) Aspen Publishers Inc., Gaithersburg, Maryland.

21. Kaneria, E.B., Karabulut, I. and Topcu, A. (2012a). Some Compositional Properties of Main Malatya apricot (Prunus armeniaca L.)Varieties. Food Chem. 107(2):939-948.

22. Kareem, S.O. and Adebowale, A.A (2007). Clarification of orange juice by crude fungal pectinase from citrus peel. Nig. Food J. 25(1):130-137.

23. Lacey AH, Artik N, Simsek A, Gunes N (2009). Nutrient Composition of Hazenut (Corylus avellana L.) varieties cultivated in Turkey. Food Chem. 99(3); 509-515.

24. Landon S. (2007). Fruit juice nutrition and health (Review). Food Australia 59 (11):533538.

25. Mannay S. and Shadaksharaswany CM (2005). Foods: Facts and Principles. (2nd ed.). New Age International Ltd. Publishers. New Delhi, India.

26. Munguti, J.M., Liti, D. M., Waidbacher, H., Straif, M. and Zollitsch, W. (2006) Proximate composition of selected potential feedstuffs for Nile tilapia (Oreochromis niloticus Linnaeus) production in Kenya, Die Bodenkultur, 57 (3), 131-141.

27. Naseem, U., Javid, A., Farhat, A. K., Muhammad, K., Arshad, H., Inayat-urRahman, Zia-ur-Rahman and Shafqatullah (2012) Proximate Composition, minerals content, antibacterial and antifungal activity evaluation of pomegranate (Punica granatum L.) peels powder, Middle-East Journal of Scientific Research, 11 (3), 396-401.

28. Nwachuku, M. and Ezejiaku, A.M. (2014). Nutritional and Chemical Evaluation for Pomegranate (Punica granatum L.) Fruit Peel and Seeds Powders by Products. Middle East J. Appl. Sci., 3:169-179.

29. Okai, B. D., Bateng, M., Amoah, K. O. and Aning, J. (2010) The effects of dried pawpaw peels meal (DPPM) on the growth performance and carcass characteristics of Albino rats, In Proceeeding of the 30th GAZA Conference, ABI-FAFRAHAACCRA, Ghana, 118-123.
30. Omutubga, S. K., Ashifat, A. A., Kehinde, A. S., Olayinke, O. O. and Edugbola, G.O. (2012) Proximate evaluation of nutritional value of Mango (Mangifera indica), International Journal of Research in Chemistry and Environment, 2 (4), 244-245.

31. Potter H. and Hotchkiss I (2006). Food Science. (5th ed.). CBS Publishers and Distributors. New Delhi, India.

32. Raheena, T. (2009). Chemical composition of Musa sapientum (banana) peels. Electron. J. Environ. Agric. Food Chem, 8: 437-442.

33. Rudrappa, A. (2009). Factors affecting yeast growth and protein yield production from orange, plantain and banana wastes processing residues using Candida spp. African J. Biotech., 7: 290-295.

34. Ukana, D. A., Aniekan, E. A. and Enin, G. N. (2012). Evaluation of proximate compositions and mineral elements in the star apple peel, pulp and seed. Journal of Basic and Applied Scientific Research, 2 (5), 48394843.

35. Umesh F.A (2009). Application of Artificial Sweeteners for Production of Low Calorie Jam. M.SC. Thesis Dept. of Food Science and Technology, Faculty of Agric. Cairo University, Egypt.

36. Wardlaw G.M (2004). Perspectives in Nutrition. (6th ed.). McGram Hill Companies, New York, U.S.A. 